\title{
Effects of vitamin antioxidant supplementation on cell kinetics of patients with adenomatous polyps
}

\author{
R J Cahill, K R O'Sullivan, P M Mathias, S Beattie, H Hamilton, C O'Morain
}

\begin{abstract}
Colonic crypt cell proliferation is used as an indicator of risk of colorectal carcinoma. Subjects with adenomatous polyps and cancer have an increased cell proliferation and a shift of the proliferative zone towards the apex of the crypt. Epidemiological and in vitro studies have confirmed a link between vitamins $A, E$, $C, \beta$-carotene, and colorectal cancer. In vitro bromodeoxyuridine immunohistochemical technique was used to assess the effect of daily oral supplementation with vitamin $E(160 \mathrm{mg})$, vitamin C (750 mg), or $\beta$-carotene $(9 \mathrm{mg})$ on the colonic crypt cell proliferation in patients with adenomatous polyps $(n=40)$ compared with normal subjects with no colonic disease $(n=20)$. The patients were given supplementation for one month and colonic biopsy specimens were taken before and at the end of the trial. Patients with adenomatous polyps had a significantly higher mean labelling index per cent than controls $(p<0.001)$. Vitamic $C$ or $\beta$-carotene supplementation, however, significantly reduced the total proliferation $(p<0.005)$ whereas vitamin $E$ supplementation had no effect on the colonic crypt cell proliferation. $\beta$-carotene reduced cell proliferation at the base of the crypt only. Vitamin C reduced cell proliferation in all the crypt compartments from the apex to the base to those values seen in age and sex matched controls. These findings indicate that prolonged supplementation with vitamin $\mathbf{C}$ may reduce the recurrence of adenomatous polyps.

(Gut 1993; 34: 963-967)
\end{abstract}

Colorectal cancer develops through a complex process from hyperproliferative mucosa to adenoma and eventually to carcinoma. ${ }^{1}$ The pathogenisis of this sequence of events is largely unknown. It is generally accepted, however, that hyperproliferation of the colorectal mucosa with a shift of the proliferative zone to the upper portion of the crypt is the first step of the sequence. ${ }^{2}$

One of the primary insults to the colonic mucosa in the complex adenoma-carcinoma sequence may be an increase in free radical activity, which has been shown to cause DNA damage $^{3}$ and gene mutations. Antioxidants are a defence against free radical activity and epidemiological studies confirm that populations with a low level of antioxidants may have a higher risk of colorectal cancer..$^{4-8}$

Vitamins A, E, and C are potent antioxidants and the serum concentrations of these antioxidants have been shown to inversely correlate with the risk of developing colorectal cancer. ${ }^{46}$ Clinical trials ${ }^{9-12}$ have assessed the effect of these antioxidant vitamins as supplements on the risk of colorectal cancer.

The aim of this study was to assess the effect of oral supplementation with vitamin $C$, vitamin $E$, or $\beta$-carotene on colonic crypt cell proliferation of patients with adenomatous polyps.

\section{Patients and methods}

Sixty nine subjects undergoing colonoscopy were recruited for this study. These were aged between 34-80, had a complete colonoscopic examination of the large bowel, were capable of following the study protocol, and gave a written informed consent.

Subjects were excluded from the study if they suffered from any debilitating or life threatening disease, including invasive cancer. Patients with familial polyposis coli, inflammatory bowel disease, malabsorption syndrome, or a personal history of colonic resection were excluded. Subjects with an incomplete examination of the large bowel, severe dysplasia, or carcinoma in situ were excluded. Any subjects taking vitamin supplements within a year of entering the trial were not included in this study.

Forty subjects with adenomatous polyps proved histologically of diameter greater than $5 \mathrm{~mm}$ were included in the final analysis. Twenty subjects with normal colonoscopy and histologically normal colonic mucosa were included as a control group. Table I shows the demographic profile of these subjects.

The patients with adenomatous polyps were assigned to one of four study groups using the random sampling quota technique allowing for 10 subjects in each study group. Group 1: no supplementation. Group 2: $160 \mathrm{mg}$ of vitamin E daily. Group 3: $750 \mathrm{mg}$ of vitamin C daily. Group 4: $9 \mathrm{mg}$ of $\beta$-carotene daily. The supplementation dose was given for one month, in two or three tablets with meals. Vitamin supplements were kindly donated by Natures Own, West Malvern, United Kingdom.

Colonic biopsy specimens were taken before and at the end of the supplementation period. The colonoscopies were carried out between 1100 and 1300 to allow for diurnal variation in proliferation rates. ${ }^{13}$ Four pinch biopsy specimens were taken for cell proliferation analysis from macroscopically normal mucosa in the

TABLE I Demographic profile of the study groups

\begin{tabular}{llllc}
\hline Study group & $(n)$ & $\begin{array}{l}\text { Age mean } \\
(S D)\end{array}$ & $\begin{array}{l}\text { Age range } \\
(y)\end{array}$ & Men:women \\
\hline No supplement & 10 & $60(2 \cdot 0)$ & $41-77$ & $5: 5$ \\
Vitamin E & 10 & $62(2 \cdot 8)$ & $43-73$ & $7: 3$ \\
Vitamin C & 10 & $60(2 \cdot 5)$ & $53-73$ & $7: 3$ \\
B-carotene & 10 & $63(4 \cdot 5)$ & $34-80$ & $3: 7$ \\
Normal subjects & 20 & $61(3 \cdot 8)$ & $34-80$ & $10: 10$ \\
\hline
\end{tabular}


Figure 1: Comparison of the total labelling index per cent (LI\%) of all the study groups before and at the end of the trial (mean, $S E M$ ). ${ }^{\star} p<0.005$ when compared with values before supplementation. $t p<0.001$ when compared with patients with a history of adenomatous polyps.

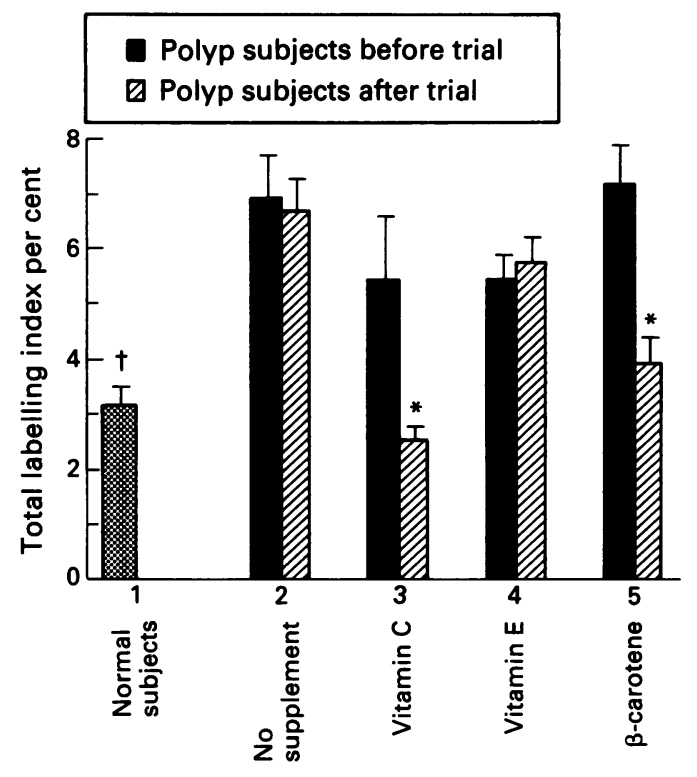

Trial groups

sigmoid colon, $20 \mathrm{~cm}$ from the anus, to control for the anatomical difference in cell proliferation. ${ }^{14}$ These were immediately placed in modified Waymouth's medium. Twenty mls of whole blood was also collected into empty vacutainers before and at the end of the one month trial period for analysis of serum vitamins, as an assessment of compliance to the supplementation. Compliance was also confirmed by a tablet count.

CELL PROLIFERATION TECHNIQUE ${ }^{15}$

In vitro incorporation of bromodeoxyuridine was achieved by culturing the biopsy specimens in Waymouth's medium (Flow Labs, Scotland) supplemented with $10 \%$ fetal calf serum, $1 \mathrm{mM}$ glutamine and gentamicin, $50 \mu \mathrm{M}$ bromodeoxyuridine (Sigma Co, Poole, United Kingdom, and $5 \mu \mathrm{M}$ fluorodeoxyuridine (Sigma Co, Poole, United Kingdom. The biopsy specimens were incubated in the medium for one hour at 101.3 $\mathrm{kPa}$ of pressure in a sealed modular incubation chamber (Flow Labs, Hertfordshire, United Kingdom) previously infused with $95 \%$ oxygen and $5 \%$ carbon dioxide at a thermoregulated temperature of $37^{\circ} \mathrm{C}$. The biopsy specimens were fixed in Carnoy's fixative overnight and embedded in paraffin wax.

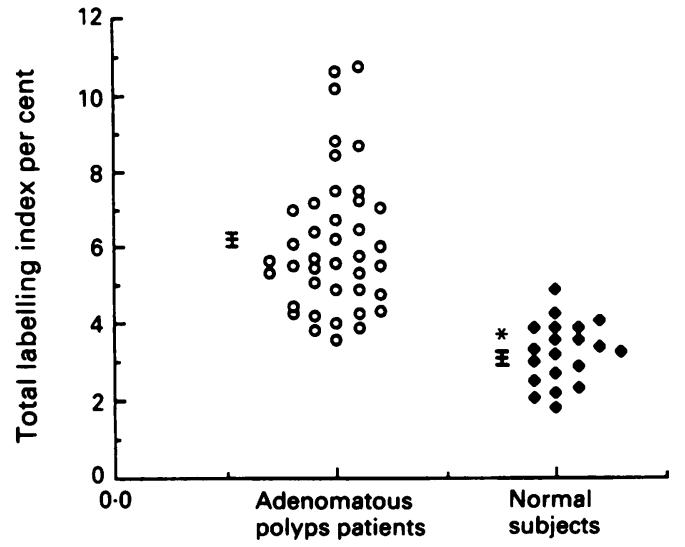

Figure 2: Individual LI\% of subjects with adenomatous polyps and controls (mean, SEM). ${ }^{\star} p<0.01$ compared with polyp subjects.

Immunohistochemical detection of the bromodeoxyuridine incorporation was carried out on $4 \mu \mathrm{m}$ sections. After deparafinisation and rehydration through alcohol to phosphate buffered saline, endogenous peroxide activity was blocked by immersing the sections in 5\% $\mathrm{H}_{2} \mathrm{O}_{2}$ in methanol. The biopsy DNA was denatured by incubation in $1 \mathrm{M} \mathrm{HCl}$ at $60^{\circ} \mathrm{C}$ for eight minutes. The sections were incubated in $5 \%$ normal rabbit serum to reduce background staining and then incubated with the monoclonal antibody to bromodeoxyuridine (Dakopatts, Denmark) diluted 1:100 with phosphate buffer for one hour. The slides were then washed in phosphate buffered saline and incubated with a 1:300 dilution of biotinylated anti-mouse antibody (Dakopatts, Denmark). After further washings in phosphate buffered saline the slides were incubated with peroxidase conjugated strepavidin diluted 1:400, washed in phosphate buffered saline and the labelled cells were visualised by the diaminobenzidine reaction and lightly counterstained with haematoxylin.

\section{IMMUNOHISTOLOGICAL ANALYSIS}

A mean of 20 sections were examined for each subject. Only crypts longitudinally sectioned and visible in their entire length were analysed. A mean number of 10 well orientated crypts were examined for each specimen.

Labelling index per cent (LI\%) was measured by counting the number of bromodeoxyuridine-

TABLE II Cell kinetics of macroscopically normal mucosa of all study groups before and after supplementation

\begin{tabular}{|c|c|c|c|c|c|c|c|c|}
\hline & \multicolumn{2}{|c|}{ No supplement } & \multicolumn{2}{|l|}{ Vitamin $C$} & \multicolumn{2}{|l|}{ Vitamin $E$} & \multicolumn{2}{|l|}{$\beta$-Carotene } \\
\hline & Before trial & After trial & Before trial & After trial & Before trial & After trial & Before trial & After trial \\
\hline No of subjects. & & & & & 10 & & & \\
\hline $\begin{array}{l}\text { Crypts per subject } \\
\text { Total cells counted }\end{array}$ & $12(0 \cdot 4)$ & $2(0 \cdot 6)$ & $1(0 \cdot 2)$ & & $11(0 \cdot 3)$ & & & \\
\hline per subject & $1190(46)$ & $1193(39)$ & $1279(37)$ & $1466(74)$ & $1247(63)$ & $1376(61)$ & $1256(65)$ & $1326(47)$ \\
\hline $\begin{array}{l}\text { Total labelled cells } \\
\text { per subject } \\
\text { Total cells per crypt } \\
\text { LI\% total } \\
\text { LI\% per compartment }\end{array}$ & $\begin{array}{c}82(6 \cdot 9) \\
99(4 \cdot 5) \\
6 \cdot 9(0 \cdot 7)\end{array}$ & $\begin{array}{c}77(8 \cdot 3) \\
99(4 \cdot 7) \\
6 \cdot 6(0 \cdot 8)\end{array}$ & $\begin{array}{c}68(5 \cdot 6) \\
121(4 \cdot 7) \\
5 \cdot 4(0 \cdot 3)\end{array}$ & $\begin{array}{c}39(4 \cdot 3) \\
149(5 \cdot 6) \\
2 \cdot 5(0 \cdot 2)^{\star}\end{array}$ & $\begin{array}{c}68(6 \cdot 1) \\
115(4 \cdot 4) \\
5 \cdot 4(0 \cdot 3)\end{array}$ & $\begin{array}{c}76(5 \cdot 7) \\
114(4 \cdot 5) \\
5 \cdot 7(0 \cdot 4)\end{array}$ & $\begin{array}{c}88(7 \cdot 3) \\
127(7 \cdot 9) \\
7 \cdot 1(0 \cdot 7)\end{array}$ & $\begin{array}{c}50(4 \cdot 5) \\
129(5 \cdot 1) \\
3 \cdot 9(0 \cdot 4)^{\star}\end{array}$ \\
\hline $\begin{array}{l}\text { LI\% 1 } \\
\text { LI\% 2 } \\
\text { LI\% 3 } \\
\text { LI\% 4 } \\
\text { LI\% 5 }\end{array}$ & $\begin{array}{r}0.5(0.2) \\
2.4(0.5) \\
6.8(0.8) \\
12.5(0.9) \\
12.5(1.3)\end{array}$ & $\begin{array}{r}0 \cdot 5(0 \cdot 2) \\
2 \cdot 0(0 \cdot 5) \\
6 \cdot 5(0 \cdot 6) \\
10 \cdot 5(1 \cdot 0) \\
12 \cdot 0(1 \cdot 4)\end{array}$ & $\begin{array}{c}0 \cdot 08(0 \cdot 1) \\
1 \cdot 7(0 \cdot 5) \\
6 \cdot 5(0 \cdot 6) \\
10 \cdot 3(0 \cdot 8) \\
8 \cdot 2(1 \cdot 3)\end{array}$ & $\begin{array}{l}0.03(0 \cdot 03) \\
0.3(0 \cdot 1) \dagger \\
2 \cdot 2(0 \cdot 4)^{\star} \\
4.5(0 \cdot 4)^{\star} \\
5 \cdot 7(0.5)^{\star}\end{array}$ & $\begin{array}{l}0.05(0.1) \\
1.7(0.4) \\
4.8(0.7) \\
9.9(0.9) \\
9.4(0.7)\end{array}$ & $\begin{array}{r}0 \cdot 2(0 \cdot 1) \\
2 \cdot 0(0 \cdot 6) \\
7 \cdot 4(0 \cdot 8) \\
11 \cdot 0(1 \cdot 1) \\
7 \cdot 4(0 \cdot 8)\end{array}$ & $\begin{array}{r}0 \cdot 2(0 \cdot 1) \\
1 \cdot 8(0 \cdot 3) \\
5 \cdot 7(0 \cdot 6) \\
13 \cdot 8(1 \cdot 5) \\
13 \cdot 5(1 \cdot 5)\end{array}$ & $\begin{array}{l}0 \cdot 2(0 \cdot 1) \\
1 \cdot 3(0 \cdot 2) \\
4 \cdot 4(0 \cdot 8) \ddagger \\
7 \cdot 2(3 \cdot 0)^{\star} \\
6 \cdot 7(2 \cdot 1) \ddagger\end{array}$ \\
\hline
\end{tabular}

All results expressed as mean $(S E M) ;{ }^{\star} p<0.005, \nmid p<0.05, \neq p<0.01$ when compared with values before supplementation; LI\%=labelling index per cent. 

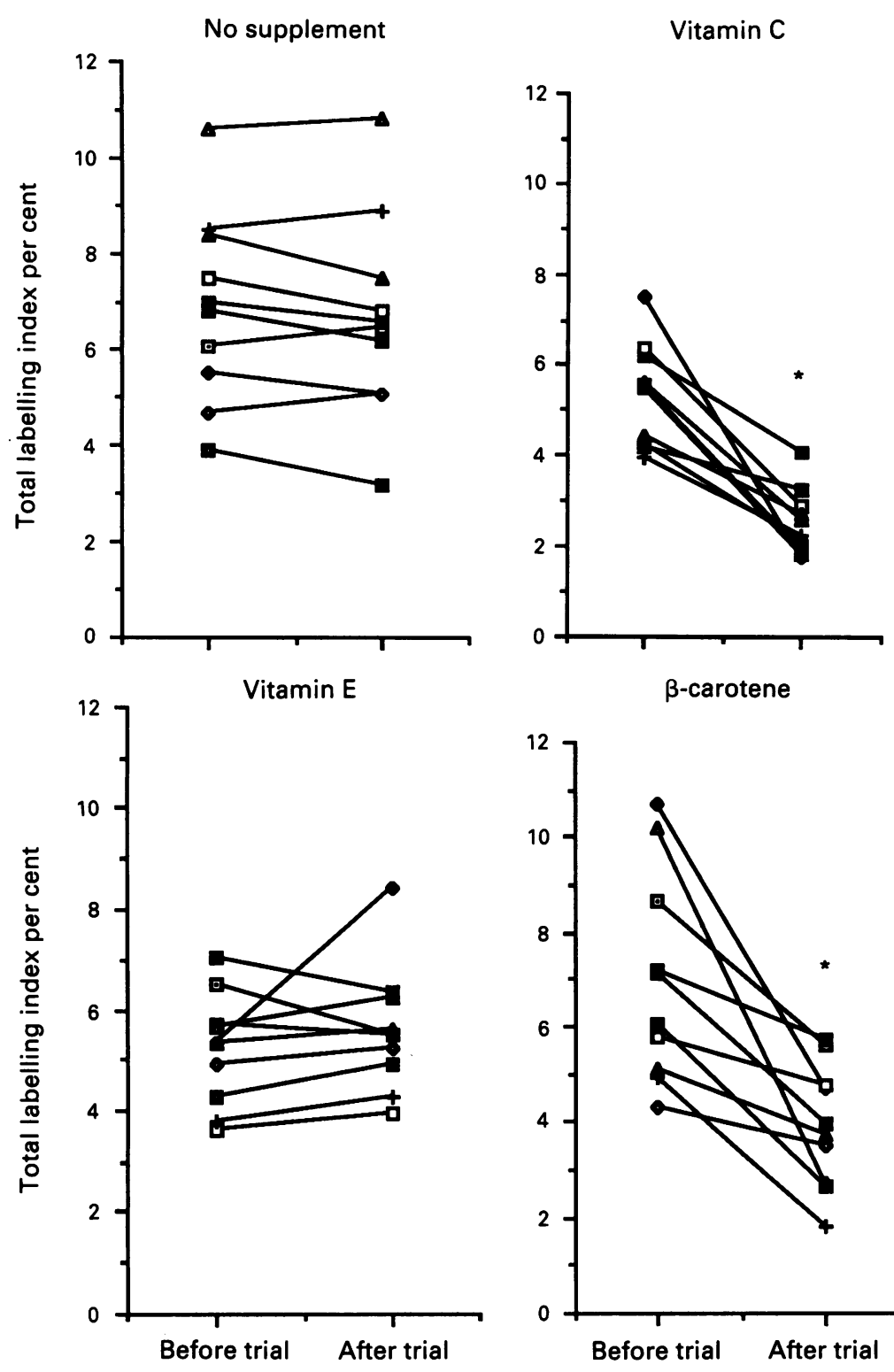

$\beta$-carotene

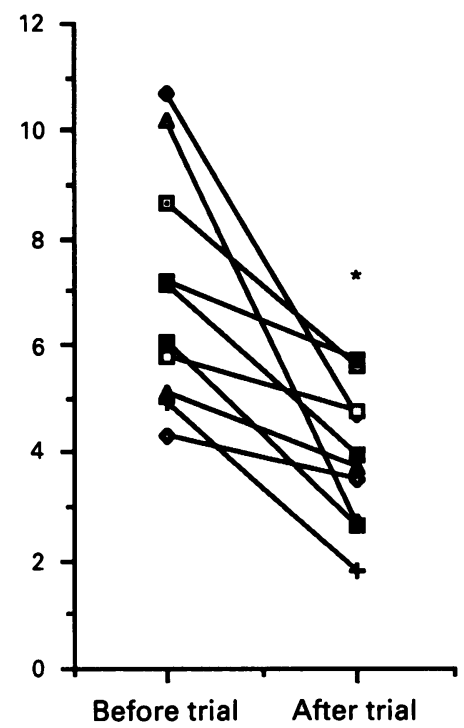

Figure 3: Individual LI\% of each adenomatous polyp subject. ${ }^{\star} p<0.005$ compared with values before the trial.

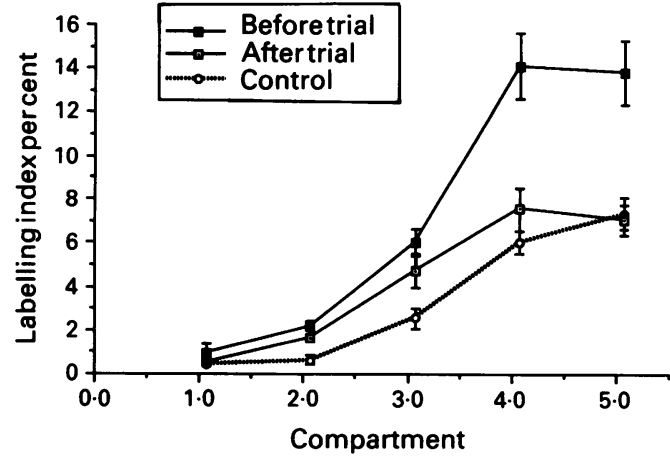

Figure 4: Comparison of the compartmental LI\% before and after supplementation of the $\beta$-carotene group and age and sex matched controls (mean, SEM).

compartment. The samples were analysed blind by a single observer.

SERUM ANALYSIS OF VITAMINS

Serum analysis of vitamins was performed as a method of assessing compliance. The serum was stored at $-20^{\circ} \mathrm{C}$ until all samples were collected. Retinol, $\beta$-carotene, vitamin $C$, and $\alpha$-tocopherol were analysed using high performance liquid chromatography. Plasma cholesterol was measured by a Boehringer Mannheim GmbH kit (Mannheim, Germany). The $\alpha$-tocopherol values were expressed as a ratio of $\alpha$-tocopherol to cholesterol values.

\section{STATISTCAL ANALYSIS}

The total LI\% and the LI\% per compartment was compared before and after supplementation in each group. Serum vitamin values were compared before and after the supplementation period. The significance was analysed using the Signed Rank Sum test.

\section{Results}

Forty nine patients with adenomatous polyps were recruited into this study, nine were not included in the final analysis (five were lost to follow up, two were diagnosed with upper gastrointestinal cancer, one died of a myocardial infarction, and one patient in the $\beta$-carotene group was not compliant). Patients were deemed compliant for this study on the basis of a

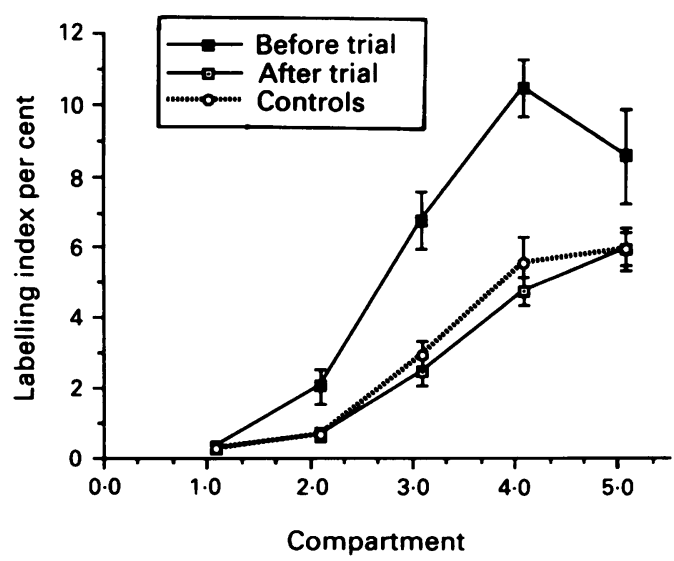

Figure 5: Comparison of the compartmental LI\% before and after supplementation of the vitamin $C$ group and age and sex matched controls (mean, SEM).
TABLE III Comparison of cell proliferation indices of $\beta$-carotene and vitamin $C$ study groups after trial to age and sex matched controls

\begin{tabular}{|c|c|c|c|c|}
\hline & \multicolumn{2}{|l|}{ Vitamin $C$} & \multicolumn{2}{|l|}{$\beta$-Carotene } \\
\hline & Normal subjects & After trial & Normal subjects & After trial \\
\hline $\begin{array}{l}\text { No of subjects } \\
\text { Age } \\
\text { Men:women } \\
\text { Total cells counted } \\
\text { Total labelled cells } \\
\text { Total LI\% }\end{array}$ & $\begin{array}{c}10 \\
60(2 \cdot 0) \\
7: 3 \\
1652(68) \\
54(6 \cdot 8) \\
3 \cdot 1(0 \cdot 2)\end{array}$ & $\begin{array}{c}10 \\
60(2 \cdot 5) \\
7: 3 \\
1466(4 \cdot 3) \\
39(4 \cdot 3) \\
2 \cdot 5(0 \cdot 2)\end{array}$ & $\begin{array}{c}10 \\
63(5 \cdot 0) \\
3: 7 \\
1474(72) \\
44(3 \cdot 2) \\
3 \cdot 0(0 \cdot 3)\end{array}$ & $\begin{array}{c}10 \\
63(4 \cdot 5) \\
3: 7 \\
1326(47) \\
50(4 \cdot 5) \\
3 \cdot 9(0 \cdot 4)^{\star}\end{array}$ \\
\hline $\begin{array}{l}\text { LI\% per compartment } \\
\text { LI\% 1 (apex) } \\
\text { LI\% 2 } \\
\text { LI\% 3 } \\
\text { LI\% 4 } \\
\text { LI\% 5 (base) }\end{array}$ & $\begin{array}{l}0 \\
0 \cdot 4(0.2) \\
2 \cdot 7(0 \cdot 4) \\
5 \cdot 3(0.7) \\
5 \cdot 9(0.5)\end{array}$ & $\begin{array}{l}0.03(0.03) \\
0.3(0 \cdot 1) \\
2 \cdot 2(0 \cdot 4) \\
4 \cdot 5(0 \cdot 4) \\
5 \cdot 7(0.5)\end{array}$ & $\begin{array}{l}0.08(0 \cdot 1) \\
0 \cdot 3(0 \cdot 2) \\
2 \cdot 2(0 \cdot 5) \\
5 \cdot 7(0 \cdot 5) \\
7 \cdot 0(0 \cdot 7)\end{array}$ & $\begin{array}{l}0 \cdot 15(0 \cdot 1) \\
1 \cdot 3(0 \cdot 2) \dagger \\
4 \cdot 4(0 \cdot 8) \dagger \\
7 \cdot 2(0 \cdot 1)^{\star} \\
6 \cdot 7(0 \cdot 7)^{\star}\end{array}$ \\
\hline
\end{tabular}

All results expressed as mean (SEM); $\mathrm{p}_{0}<0.005, \mathrm{tp}<0.05$ when compared with age and sex matched controls; $\mathrm{LI} \%=$ labelling index per cent.

positive cells and expressing the result as The relative positions of the positive cells in the crypt were noted. For cell kinetics evaluation equal size. The compartments were referred to by the ordinal numbers from 1 (apex) to 5 (base) and the labelling index calculated for each 
significant rise in serum concentrations of the supplemented vitamin and a correct tablet count.

On analysis of the total labelling index per cent (Figs 1 and 2) patients with adenomatous polyps had significantly higher mean (SEM) LI\% (6.2 $(0 \cdot 3))$ compared with normal controls $(3 \cdot 2(0 \cdot 3))$, $\mathrm{p}<0.001$. When the LI\% was analysed before and after the trial (Table II) it was found that the total LI\% or compartmental LI\% did not change over the one month period in the absence of supplementation (Figs 1 and 3).

$\beta$-carotene supplementation significantly reduced the total LI\% $(p<0.005)$ (Figs 1 and 3). On compartmental analysis (Table II) the proliferation at the base of the crypt (compartments 3,4 , and 5) was significantly reduced, however, there was no significant reduction at the apex of the crypt (compartments 1 and 2). When the total LI\% was compared with that of age and sex matched controls (Table III), it was found that although $\beta$-carotene reduced the total LI\% it did not reduce it to control values (Fig 4).

Vitamin C supplementation significantly reduced the total LI\% $(p<0.005)$ (Figs 1 and 3$)$. On compartmental analysis, proliferation in all compartments was significantly reduced (Table II). When these were compared with age and sex matched controls (Table III), no significant difference was seen in any of the labelling indices (Fig 5).

Vitamin E supplementation had no effect on the increased proliferation found in patients with adenomatous polyps.

\section{Discussion}

This study assessed the effect of antioxidant vitamin supplementation on colonic crypt cell proliferation $^{16}$ in patients with adenomatous polyps of the colon. In contrast with other vitamin supplementation studies, ${ }^{9-12}$ this study assessed the effect of single vitamin supplements only, the study was prospective with a control group, subjects with familial polyposis coli were excluded and subjects were sequentially assigned to each group.

Subjects with adenomatous polyps had an increased cell proliferation with an increasing trend of proliferating cells towards the apex of the crypt as has been found by others. ${ }^{14-17} \mathrm{We}$ found that vitamin $E$ supplementation had no effect on this abnormal proliferation. $\beta$-carotene and vitamin $C$ supplementation significantly reduced the total cell proliferation. $\beta$-carotene did not change the shift of the proliferative zone towards the apex of the crypt and the indices of proliferation taken after supplementation were not reduced to those found in age and sex matched controls. Vitamin $\mathrm{C}$ reduced the cell proliferation to that found in age and sex matched controls, it also reduced the upward shift in the proliferative zone.

Although the mean LI\% of subjects with adenomatous polyps was significantly higher than those with no colonic disease $(p<0.001)$, there was an overlap in the total LI\% of both groups (Fig 2). It is possible that the younger control subjects with a high LI\% may develop an adenomatous polyp as an ageing phenomenon.
Paganelli et $a l^{18}$ found that there was no significant difference in the LI\% between subjects with a small adenoma $(<1 \mathrm{~cm})$, single large adenoma, multiple small adenomas, multiple adenomas including at least one large, colorectal cancer, and no colorectal disease. Our results agree with studies carried out by Roncucci et al, ${ }^{17}$ Bleiberg et al, ${ }^{16}$ and Terpstra et al,${ }^{14}$ however, who have all found that subjects with adenomatous polyps had a significantly higher labelling index than those with no colonic disease.

The increased proliferation and the significant upwards trend of the proliferating cells towards the apex of the crypt, seen in patients with adenomatous polyps, is a product of the increased S-phase duration of the pre-malignant cells and may be specifically related to cancer. ${ }^{16} \mathrm{~A}$ mucosa without histological signs of malignancy but with an increased S-phase duration, would indicate that the malignant process has started. ${ }^{16}$

Most studies assessing cell proliferation have used the tritiated thymidine immunohistochemical technique. The bromodeoxyuridine immunohistochemical technique has overcome many of the problems associated with the tritiated thymidine technique and the accuracy of this technique has been verified by Lacy et al. ${ }^{19}$ They found it to be as accurate and reliable as the tritiated thymidine autoradiography technique, the gold standard for the histological study of cell proliferation when examining mucosa of the digestive tract. The bromodeoxyuridine technique has many advantages over this technique as it is complete in 3-4 days compared with 14 days for tritiated thymidine and furthermore the reaction is found in the plane of the tissue section facilitating rapid cell counting. Proliferating cell nuclear antigen immunohistochemical technique although a promising method of assessing cell proliferation has yet to be fully standardised.

Evidence linking vitamin antioxidants and cancer obtained from epidemiological studies is conflicting. ${ }^{5620-22}$ We recently assessed serum concentrations of vitamin $A$ and $E$ in Irish subjects with adenomatous polyps and colorectal cancer. ${ }^{4}$ We found lower values of vitamin $\mathrm{E}$ in these subjects compared with healthy controls $(12.5 \mu \mathrm{M} v 16.4 \mu \mathrm{M}, \mathrm{p}<0.005)$ and lower vitamin $A$ values in patients with colorectal carcinoma compared with controls $(1.33 \mu \mathrm{M} v$ $1.5 \mu \mathrm{M}, \mathrm{p}<0.005)$. Stronger evidence provided by in vitro studies has confirmed the link between vitamins $A, E, C$, and $\beta$-carotene and colonic cancer. ${ }^{23-25}$

A large prospective study by Wald et $a l^{20}$ found that serum vitamin $E$ values in subjects who subsequently developed colorectal cancer were no different to those of age and sex matched controls. In vitro work has also shown that vitamin $E$ has no effect on the regression of induced tumours, which would validate our findings in this study.

Few studies have been carried out assessing the effect of vitamin supplementation on adenomatous polyps or colorectal cancer. De Cosse et $a l^{\prime \prime}$ found vitamin $\mathrm{C}$ and vitamin $\mathrm{E}$ supplementation had no effect on polyp recurrence, but in that study the supplements were taken in combination with fibre supplementation. Bussey et $a l^{9}$ examined the effect of vitamin $\mathrm{C}$ supple- 
mentation on cell proliferation using the tritiated thymidine technique. They found that supplementation reduced the total cell proliferation although in contrast with our results, vitamin C did not change the upward shift of the proliferative zone.

In conclusion this study has shown that both $\beta$-carotene and vitamin $C$ supplementation reduce the abnormal colonic crypt cell proliferation found in subjects with adenomatous polyps. Short term supplementation with vitamin C reduces the cell proliferation to normal values possibly by reducing the $S$-phase duration. This may reduce the risk of progression to carcinoma and the recurrence of adenomatous polyps. Long term studies will be needed to assess if this effect is maintained.

1 Friedman EA. A multistage model for human colon carcinoma development integrating cell culture studies with pathology. Cancer Invest 1985; 5: 453-61.

2 Lipkin M. Biomarkers of increased susceptibility to gastrointestinal cancer: New application to studies of cancer prevention in human subjects. Cancer Res $1988 ; 48: 235-45$.

$3 \mathrm{~K}$ nutila S. Role of free radicals in genetic damage (mutation). Med Biol 1984; 62: 110-4

4 O'Sullivan KR, Mathias, PM, Tobin A, O'Morain C. Risk of adenomatous polyps and colorectal cancer in relation to serum antioxidants and cholesterol status. Eur $\mathcal{F}$ Gastroemterol Hepatol 1991; 3: 775-9.

5 Tomkin GH, Scott L, Ogbuah C, O'Shaughnessy M. Carcinoma of the colon: association with low dietry vitamin A in females: preliminary communications. $\mathcal{f} R$ Irish Soc Med 1986; 79: 642-4.

6 Salonen JT, Salonen R, Lappetelainen R, Maenpaa PH Alfthan G, Puska P. Risk of cancer in relation to serum concentrations of selenium and vitamin $\mathrm{A}$ and $\mathrm{E}$ : matche case-control analysis of prospective data. $B M F 1985 ; 290$ 417-20.

7 Schrober SE, Comstock GW, Helsing KJ, Salkeld RM, Morri IS, Rider AA, et al. Serological precursors of cancer 1 . Prediagnostic serum nutrients and colon cancer risk. Am $\mathscr{f}$ Epidemiol 1987; 126: 1033-41.

8 Willet WC, Polk BF, Morris JS, Stampfer MJ, Pressel S, Rosner B, et al. Prediagnostic serum selenium and risk of cancer. lancet 1983; ii: $130-4$.

9 Bussey HJR, DeCosse JJ, Deschner EE, Eyers AA, Lesser
ML, Morson BC, et al. A randomised trial of ascorbic acid in polyposis coli. Cancer 1982; 50: 1434-9.

10 McKeown-Eyssen G, Holloway C, Jazmaji V, Bright-See E Dion $P$, Bruce WR. A randomized trial of vitamins $C$ and $E$ in the prevention of the recurrence of colorectal polyps. Cancer Res 1988; 48: 4701-5.

11 De Cosse JJ, Miller HH, Lesser ML. Effect of wheat fibre and vitamins $\mathrm{C}$ and $\mathrm{E}$ on rectal polyps in patients with adenomatous polyposis. $\mathcal{F}$ Natl Cancer Inst 1989; 81: 1290-7.

12 De Cosse JJ, Adams MB, Kuzma JF, LoGerfo P, Condon RE. Effect of ascorbic acid on rectal polyps of patients with familial polyposis. Surgery 1975; 78: 608-12.

13 Buchi KN, Moore JG, Hrushesky WJM, Southern RB, Rubin NH. Circadian rhythm of cellular proliferation in the human NH. Circadian rhythm of cellular proliferation in
rectal mucosa. Gastroenterology 1991; 101: 410-5.

14 Terpstra OT, van Blankenstein M, Dees J, Eilers GAM Abnormal pattern of cell proliferation in the entire colonic mucosa of patients with colon adenoma or cancer. Gastroenterology 1987; 92: 704-8.

15 Risio M, Coverlizza S, Ferrari A, Candelaresi L, Rossini FP Immunohistochemical study of epithelial cell proliferation in hyperplastic polyps, adenomas, and adenocarcinomas of the large bowel. Gastroenterology 1988; 94: 899-906.

16 Bleiberg $\mathrm{H}$, Buyse M, Galand P. Cell kinetic indicators of premalignant stages of colorectal cancer. Cancer 1985; 56: 124-9.

17 Roncucci L, Scalmati A, Ponz de Leon M. Pattern of cell kinetics in colorectal mucosa of patients with different types of adenomatous polyps of the large bowel. Cancer 1991; 68: 873-8.

18 Paganelli GM, Biasco G, Santucci R, Brandi G, Lalli AA, Miglioli $M$, et al. Rectal cell proliferation and colorectal cancer risk level in patients with nonfamilial adenomatous polyps of the large bowel. Cancer 1991; 68: 2451-4.

19 Lacy ER, Kuwayama H, Cowart KS, King JS, Deutz AH Sistrunk S. A rapid, accurate immunohistochemical method to label proliferating cells in the digestive tract. A comparison with tritiated thymidine. Gastroenterology 1991; 100: Son with 62 .

20 Wald NJ, Thompsin SG, Densem JW, Boreham J, Bailey A. Serum vitamin $E$ and subsequent risk of cancer. $B r f C a n c e r$ Serum vitamin E

21 Paganin-Hill A, Chao A, Ross RK, Henderson BE. Vitamin A, b-carotene, and the risk of cancer: A prospective study. $\mathcal{F}$ Natl Cancer Inst 1987; 79: 443-8.

22 Newberne PM, Beuche D, Riengropitak S, Schrager TF. The influence of dietary levels of vitamin $A$ and fat on colon cancer. Nutr Cancer 1990; 13: 235-42.

23 Cook MG, McNamara P. Effect of dietary vitamin E on dimethylhydrazine-induced colonic tumors in mice. Cancer Res 1980; 40: 1329-31.

24 Reddy BS, Hirota N, Katayama S. Effect of dietary ascorbate on 1,2-dimethylhydrazine- or methylnitrosurea-induced

25 Wattenberg LW. Inhibition of carcinogenic and toxic effects of polycyclic hydrocarbons by phenolic antioxidants and ethoxyquin. F Natl Cancer Inst 1972; 48: 1425-30. 